\title{
Using predator distributions, diet, and condition to evaluate seasonal foraging sites: sea ducks and herring spawn
}

\author{
Eric M. Anderson ${ }^{1,5, *}$, James R. Lovvorn ${ }^{1,6}{ }^{,}$Daniel Esler ${ }^{2}$, W. Sean Boyd ${ }^{3}$, \\ Kurt C. Stick ${ }^{4}$ \\ ${ }^{1}$ Department of Zoology and Physiology, University of Wyoming, 1000 E. University Avenue, Laramie, Wyoming 82071, USA \\ ${ }^{2}$ Centre for Wildlife Ecology, Simon Fraser University, 5421 Robertson Road, Delta, British Columbia V4K 3N2, Canada \\ ${ }^{3}$ Science and Technology Branch, Environment Canada, Pacific Wildlife Research Centre, 5421 Robertson Road, Delta, \\ British Columbia V4K 3N2, Canada \\ ${ }^{4}$ Washington Department of Fish and Wildlife, La Conner District Office, PO Box 1100, La Conner, Washington 98257, USA \\ ${ }^{5}$ Present address: Centre for Wildlife Ecology, Simon Fraser University, 5421 Robertson Road, Delta, \\ British Columbia V4K 3N2, Canada \\ ${ }^{6}$ Present address: Department of Zoology, Southern Illinois University, Carbondale, Illinois 62901, USA
}

\begin{abstract}
Identifying important foraging sites for highly mobile marine predators has relied mainly on relating their distributions to broadly defined habitat data. However, understanding functional dependencies on foraging sites also requires knowledge of the relative contributions of foods to predator condition. We coupled predator distributions with measures of their diet and condition to assess the importance of Pacific herring Clupea pallasii spawning events to 2 closely related and declining sea duck species. In Puget Sound, Washington, the numerical response of scoters to spawn increased with increasing biomass of spawning herring; this response was 4 -fold greater for surf scoters Melanitta perspicillata than for white-winged scoters $M$. fusca after accounting for local differences in their abundances. In the Strait of Georgia, British Columbia, diets estimated from fatty acids and stable isotopes indicated that both scoter species gained mass by consuming spawn during late March to early April. At a site without spawn during this period, only male white-winged scoters gained mass. In contrast, body mass of male surf scoters declined appreciably before spawn became available in one study year, suggesting greater dependence on spawn for restoring depleted reserves. From winter to spring, surf scoters attained greatest body mass during late April to mid-May while migrating through southeast Alaska; during this period, plasma triglycerides suggested that fattening was not related solely to spawn consumption, yet surf scoters aggregated to consume spawn whenever it was available. Although it is not clear whether herring are essential to their population processes, surf scoters and a range of other predators for which spawning areas are clearly preferred foraging sites would likely benefit from efforts that preserve declining herring stocks.
\end{abstract}

KEY WORDS: Clupea pallasii - Herring spawn ' Melanitta fusca $\cdot$ Melanitta perspicillata . Spring migration $\cdot$ Surf scoter $\cdot$ White-winged scoter

Resale or republication not permitted without written consent of the publisher

\section{INTRODUCTION}

Human impacts on marine ecosystems threaten diverse taxa of animals and plants (Kappel 2005), leading to a need for restoration and protection. To date, efforts to identify critical foraging sites for highly mobile marine predators have relied mainly on relating distributions of target species to broadly defined habitat data (Worm et al. 2003, Louzao et al. 2006). Expanded protection measures for areas in which 
marine predators predictably aggregate should reduce the risk of some impacts, such as overexploitation, bycatch, and contaminant exposure. However, to understand functional dependencies on foraging sites, we also need complementary data comparing foods in terms of their contributions to the physiological condition of predators.

During late winter and spring, many species of predators aggregate at spawning sites of the Pacific herring Clupea pallasii, which might be critical foraging areas (Høines \& Bergstad 1999, Willson \& Womble 2006). Although spawning adults and deposited eggs are seasonally preferred foods for many marine predators, it is unclear whether the nutrients obtained are uniquely essential to annual events such as migration or breeding. Of particular interest was the spawning of Pacific herring, which occurs later in spring at progressively higher latitudes (see Fig. 1; Haegele \& Schweigert 1985), so that herring and their spawn may provide seasonal pulses of food for marine birds acquiring reserves as they migrate north to breed. Scoters Melanitta spp. are sea ducks that are well-known predators of herring spawn (Munro \& Clemens 1931, Bishop \& Green 2001), and recent telemetry studies indicate that individual scoters may visit multiple spawning areas during late winter and spring (Lok 2008). Some spawning stocks of Pacific herring have declined (e.g. Carls et al. 2002, Stick 2005). However, the value of spawn relative to other marine foods that are seasonally available to scoters has not been examined.

Increasing evidence indicates that factors outside the breeding season can affect the population processes of migratory birds (Newton 2006). Waterfowl (Anatidae), in particular, can acquire substantial body fat and protein before and during spring migration (Arzel et al. 2006). These stored reserves are used to fuel migration, to meet maintenance costs on breeding grounds, and sometimes for egg production (Gauthier et al. 2003, Hobson et al. 2005). Also, migration may be timed to coincide with seasonal pulses in food availability, and declines in food during this period can adversely affect population processes (Baker et al. 2004). Nutritional constraints on non-breeding areas may contribute to long-term declines in some species of waterfowl (Anteau \& Afton 2004), yet supporting data are few. Concurrent with declines in many species of marine birds, North American populations of scoters have decreased by about $60 \%$ over the past 30 to $50 \mathrm{yr}$ (Hodges et al. 1996, Dickson \& Gilchrist 2002, Nysewander et al. 2005). However, it is unclear whether trends differ among the 3 scoter species, or whether limiting factors occur on marine habitats or on breeding areas in the sub-Arctic or Arctic.

Pacific herring spawn during the period from winter to early summer from northern Baja California to Cape
Bathurst in the Beaufort Sea, as well as in the Sea of Okhotsk and the Japan Sea (Haegele \& Schweigert 1985). Spawning events may extend along several kilometers of shoreline, with accumulations of spawn reaching 2 to $3 \mathrm{~kg}$ wet mass $\mathrm{m}^{-2}$ (Haegele 1993). Feeding by herring is typically restricted to offshore waters during non-breeding periods, so spawning events constitute major transfers of nutrients from ocean ecosystems to predators that feed mainly or exclusively in coastal habitats (Varpe et al. 2005).

Pacific herring are managed mainly by limiting fisheries harvests to a percentage of adult biomass (often $<20 \%$ ) once biomass has surpassed a minimum threshold (Stick 2005, Davidson et al. 2006, DFO 2008). As an additional management tool, regional protection measures are common for nearshore habitats of recognized value. For instance, such protection measures are often established for eelgrass Zostera spp. beds, which support diverse ecosystem processes including many herring spawning events. However, managing herring through fisheries regulations and limited protection measures for spawning habitat do not appear adequate-some spawning stocks of herring have continued to decline after suspension of commercial fisheries (Stick 2005, Willson \& Womble 2006), and nearshore habitats including eelgrass are declining worldwide (Hinrichsen 1998, Hemminga \& Duarte 2000). Such declines, together with the apparent preference of many predators for herring and their spawn, indicate a strong need for strengthening protection measures at critical spawning grounds. For such predators, however, data available to assess the importance of spawning events are limited mainly to observations of seasonal aggregations at spawning areas.

In the present study, we coupled predator distributions, body mass changes, diet biomarkers, and plasma metabolites to examine the seasonal importance of herring spawn for 2 sea duck congeners that differ appreciably in strategies of resource use during winter and spring migration. Specifically, we contrasted whitewinged scoters Melanitta fusca and surf scoters $M$. perspicillata in terms of (1) characteristics of herring spawning events that affect the numerical response of scoters to spawn and (2) effects of spawn consumption and timing on seasonal body condition of scoters.

\section{MATERIALS AND METHODS}

Study design. To evaluate the effects of multiple characteristics of herring Clupea pallasii spawning events on the number of white-winged scoters Melanitta fusca and surf scoters $M$. perspicillata that aggregate to consume spawn, we compared changes in scoter abundance to spawn data obtained by the Washington 
Department of Fish and Wildlife (WDFW). The characteristics of spawning events we considered included the biomass of spawning herring, the extent of spawn along shorelines, the initiation date of spawn deposition, and the duration of spawn availability. We conducted counts of scoters in Puget Sound and the Strait of Juan de Fuca, Washington, where related scoter studies facilitated counts for a high number of spawning areas.

We used a before-and-after control-impact design (Stewart-Oaten et al. 1986) to evaluate the influence of spawn consumption on changes in condition (i.e. body mass) of scoters captured in the southern Strait of Georgia, British Columbia (BC) during 2002 to 2003 and 2003 to 2004 . We captured scoters near spawning areas (i.e. impact sites) in mid-winter, and in early spring before and during the spawning season (Fig. 1, Table 1). Captures before spawn deposition were conducted in Baynes Sound (Area 1 in Fig. 1), where we focused on areas that our surveys indicated were most heavily used by scoters. Most scoters depart Baynes Sound for adjacent spawning areas beginning in late March (Lewis et al. 2007b, Lok et al. 2008). We captured scoters at dominant spawning areas near Baynes Sound during 1 period in 2003 and 3 periods in 2004 . We obtained information about the timing and locations of spawning events in BC from the Department of Fisheries and Oceans (DFO), which surveyed spawning areas using SCUBA (DFO 2008). Spawn deposition in a given area generally occurs in one or more separate waves of spawning activity that collectively last up to 6 wk (Haegele \& Schweigert 1985). The timing of spawn availability overlapped for spawning areas near Baynes Sound. However, during each period, we observed large flocks of scoters at only a single spawning area where we conducted captures. To evaluate the importance of spawn consumption versus endogenous regulation of reserves, we captured scoters in 2004 near White Rock, BC (Area 5 in Fig. 1). At that site, the DFO had not reported appreciable deposition of spawn in recent years (i.e. control or non-spawn site), although formal spawn surveys had not been conducted there since 1992 (DFO 2008). The WDFW documented spawn in Washington during 2004, within $10 \mathrm{~km}$ of our captures near White Rock, but we did not observe spawn or evidence of scoters feeding on spawn at these capture locations. Captures near White Rock occurred at about the same times as spring captures before and during spawn availability in and near Baynes Sound (Table 1).

We evaluated the effects of spawn consumption on surf scoter condition during the peak of spring migration in SE Alaska during 2005 and 2006 (Fig. 1). Scoter captures required significant infrastructure and field support that was available only in BC, so we collected scoters in SE Alaska. Related census and telemetry studies indicated that by late April to May most scoters had departed heavily used wintering areas at SE Vancouver Island, BC, and in northern Puget Sound (W. S. Boyd \& D. R. Nysewander, WDFW, unpubl. telemetry data). During this time, $<1 \%$ of scoters in SE Alaska consisted of white-winged scoters (E. K. Lok, Simon Fraser University, unpubl. data). About half of 75 surf scoters fitted with satellite transmitters between Baja, Mexico, and the Strait of Georgia, BC, migrated north to SE Alaska before turning inland to breeding areas, rather than turning inland from coastal regions further south (S. E. Wainwright-De la Cruz, USGS San Francisco Bay Estuary Field Station, unpubl. data). In SE Alaska, we collected surf scoters in 2 areas in 2005 and in 3 areas in 2006. Collection sites and periods (Fig. 1, Table 1) were based on the dominant northward progression of surf scoter flocks as determined by tele-

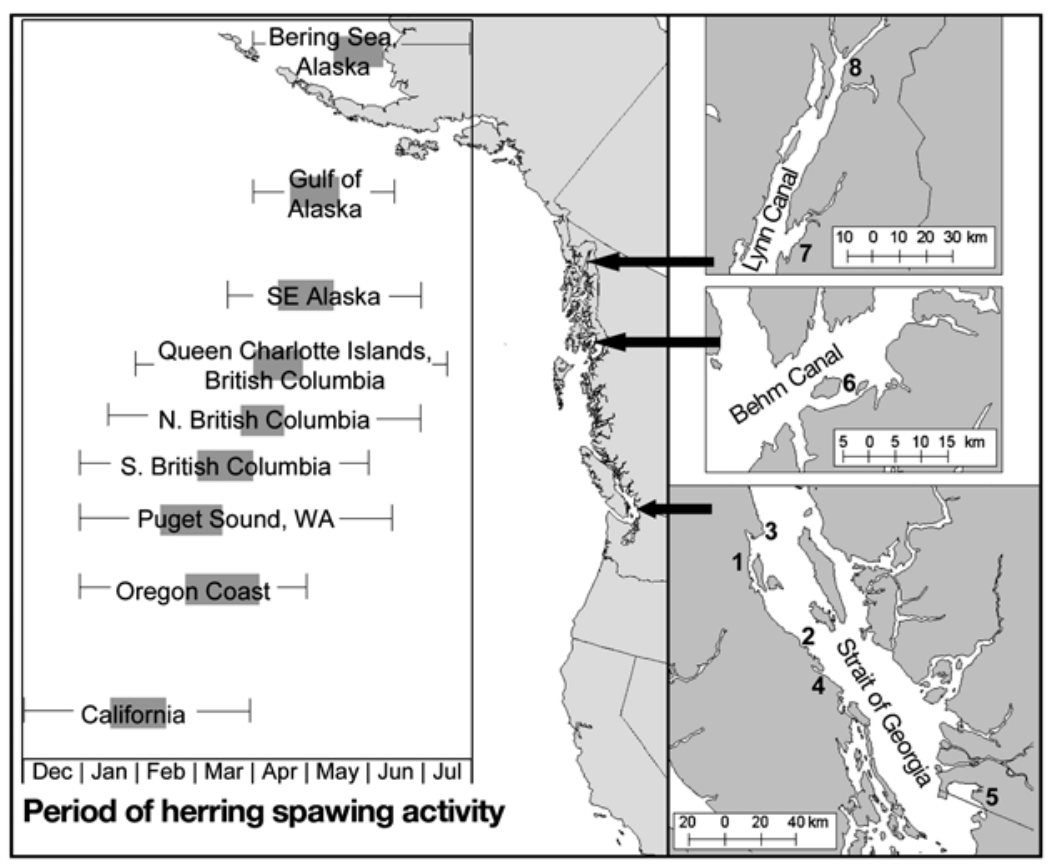

Fig. 1. Clupea pallasii, Melanitta spp. Spawning of Pacific herring occurs later in spring at progressively higher latitudes. For each location, bracketed lines and gray bars indicate the typical duration and peak period of spawning activity, respectively (Haegele \& Schweigert 1985, Stout et al. 2001). Map insets show the locations of our scoter captures in the southern Strait of Georgia, BC, and of our scoter collections in SE Alaska. See Table 1 for numbered locations and dates 
Table 1. Melanitta fusca, M. perspicillata. Dates of whitewinged and surf scoter captures (BC, Canada), surf scoter collections (SE Alaska, USA), and initial dates of local spawn deposition from 2002 to 2006. Numbering of sites corresponds to numbers in Fig. 1. Spawning activity typically lasts for 3 to $6 \mathrm{wk}$ after initial spawn deposition (Haegele \& Schweigert 1985). Dates of initial spawn deposition for BC are from DFO (2008) and for Berner's Bay are from the Alaska Department of Fish and Game (Pritchett et al. 2007). Dates were not available for Behm Canal, although oesophagi of surf scoters collected at this location contained spawn on all collection dates (E. K. Lok unpubl. data). 'None' means that agency surveys and our own observations detected no spawn locally, or that initial spawn dates occurred well after captures or collections

\begin{tabular}{|c|c|c|}
\hline $\begin{array}{l}\text { Site } \\
\text { no. }\end{array}$ & $\begin{array}{l}\text { Dates of scoter } \\
\text { captures or collections }\end{array}$ & $\begin{array}{l}\text { Initial date of local } \\
\text { spawn deposition }\end{array}$ \\
\hline \multicolumn{3}{|c|}{ Southern Strait of Georgia, BC } \\
\hline \multirow[t]{5}{*}{1} & Baynes Sound & \\
\hline & $10-16$ Dec 2002 & None \\
\hline & 24-27 Feb 2003 & None \\
\hline & 1-9 Dec 2003 & None \\
\hline & 23-27 Feb 2004 & None \\
\hline \multirow[t]{3}{*}{2} & Qualicum Beach, Qualicum Bay & \\
\hline & 24-27 Mar 2003 & 17 Mar 2003 \\
\hline & 15-19 Mar 2004 & 12 Mar 2004 \\
\hline \multirow[t]{2}{*}{3} & Kye Bay, Point Holmes & \\
\hline & 29 Mar-2 Apr 2004 & 9 Mar 2004 \\
\hline \multirow[t]{2}{*}{4} & Lantzville & \\
\hline & 6-9 Apr 2004 & 11 Mar 2004 \\
\hline \multirow[t]{4}{*}{5} & White Rock & \\
\hline & 2-10 Mar 2004 & None \\
\hline & 23-26 Mar 2004 & None \\
\hline & 21-23 Apr 2004 & None \\
\hline \multicolumn{3}{|c|}{ SE Alaska } \\
\hline \multirow[t]{3}{*}{6} & Behm Canal (north of Ketchikan & \\
\hline & 27-28 Apr 2005 & Before 27 Apr 2005 \\
\hline & 25-26 Apr 2006 & Before 25 Apr 2006 \\
\hline \multirow[t]{3}{*}{7} & Berner's Bay (north of Juneau) & \\
\hline & 18-20 May 2005 & 10 May 2005 \\
\hline & 11-12 May 2006 & 12 May 2006 \\
\hline \multirow[t]{2}{*}{8} & Chilkoot Inlet (east of Haines) & \\
\hline & 16-18 Мay 2006 & None \\
\hline
\end{tabular}

metry and aerial counts (Lok 2008). We used data collected by the Alaska Department of Fish and Game to determine the timing and locations of spawning events in SE Alaska (Davidson et al. 2005, 2006, Pritchett et al. 2007).

We contrasted scoter body mass among capture and collection periods. We then used fatty acid and stable isotope analyses of scoter tissues and foods to evaluate the influence of spawn consumption on body mass. Combined use of these 2 biomarker approaches adds greater reliability to diet estimates for marine birds (Dahl et al. 2003), which was important for 2 reasons. First, stable isotope ratios in scoter tissues could vary due to factors unrelated to spawn consumption (see below). Second, selective metabolism in birds may alter the composition of fatty acids in tissues relative to those in the diet (Pierce et al. 2004, Pierce \& McWilliams 2005); yet quantitative descriptions of this process were unavailable.

We first assessed the ability of selected fatty acids and stable isotopes to distinguish spawn from other foods consumed by scoters. For these analyses, we selected 12 fatty acids that animals obtain mainly from food (Table 2; Iverson et al. 2004). Nine of these fatty acids were selected because of their relatively high prevalence, with each comprising $>0.5 \%$ of fatty acids averaged over all samples of scoter tissues and foods. The remaining 3 fatty acids included all identified nonmethylene-interrupted (NMI) fatty acids. De novo synthesis of NMI fatty acids is believed to occur only in benthic mollusks, including bivalves (Budge et al. 2007), which often comprise appreciable fractions of scoter diets before spawn becomes available (Anderson et al. 2008). We conducted a principal component analysis (PCA) on the correlation matrix of values for these 12 fatty acids in spawn and bivalves. Surf scoters, in particular, consume diverse invertebrates in addition to bivalves (Anderson et al. 2008). To evaluate the ability of stable isotopes to distinguish spawn from bivalves and many other invertebrate foods, we contrasted $\delta^{15} \mathrm{~N}$ values for spawn and representative invertebrates of dominant feeding modes. For fatty acid and stable isotope analyses, spawn and invertebrates were collected in San Francisco Bay, Puget Sound, BC, and Alaska between March and May from 2003 to 2006. We considered taxa of bivalves found in fecal samples of scoters we captured in BC (Lewis et al. 2007a), and common taxa of invertebrates found in oesophagi plus gizzards of scoters we collected in Puget Sound and SE Alaska (Anderson et al. 2008, E. K. Lok unpubl. data).

To evaluate the effect of spawn consumption on scoter condition, we regressed scoter mass for each treatment (species $\times$ sex $\times$ period) on (1) PC1 of the 12 fatty acids in scoter adipose and (2) $\delta^{15} \mathrm{~N}$ of scoter blood cells. Nutrient reserves in waterfowl may decline as winter progresses (e.g. Lovvorn 1994, Anderson \& Lovvorn 2008), and related enrichment in tissue ${ }^{15} \mathrm{~N}$ (Hobson et al. 1993) could confound a positive relationship between spawn consumption (as indicated by increased ${ }^{15} \mathrm{~N}$ in tissues) and body mass. Further, depletion of reserves may vary among scoters before spawn is available if reserves are influenced at least partly by differences among wintering locations in proximate environmental conditions (Lovvorn 1994). Thus, we evaluated $\delta^{15} \mathrm{~N}$ for scoter blood cells, which have a lower rate of protein turnover than whole blood or plasma and thus minimize enrichment of tissue ${ }^{15} \mathrm{~N}$ due to nutritional stress (Cherel et al. 2005). 


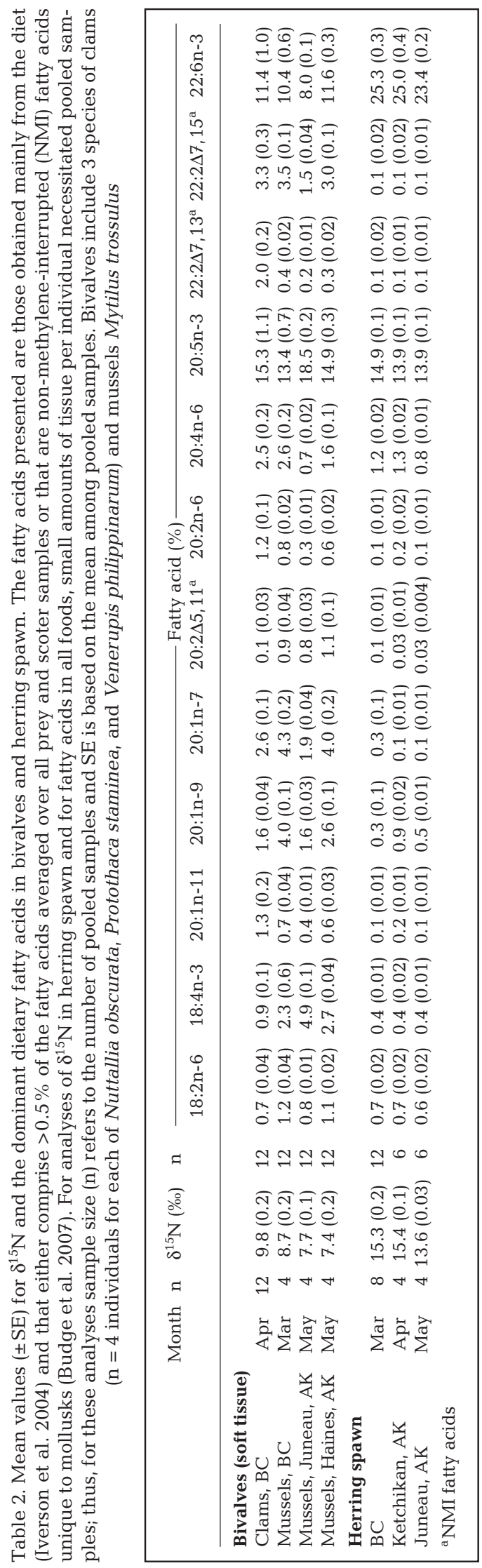

Fatty acids and stable isotopes were prepared for 6 to 12 scoters for each treatment (species $\times \operatorname{sex} \times$ period), although fewer samples were available in some cases. In most cases, the same individuals were used within each treatment for fatty acid and stable isotope analyses, but, for some treatments, numbers of individuals sampled for blood cells were greater. For male surf scoters, initial analyses indicated that variability in body mass and $\delta^{15} \mathrm{~N}$ of blood cells within each period was relatively high. Thus, for this cohort, we prepared stable isotopes for a larger number of individuals $(\mathrm{n} \approx 20)$ within each of the 3 periods during spawn availability in 2004 . To verify that any changes in scoter mass at the non-spawn site were unrelated to spawn consumption at other locations, we compared the mean $\delta^{15} \mathrm{~N}$ of blood cells for scoters captured during the period of regional spawn availability at spawn versus non-spawn sites.

We evaluated the relative importance of spawn consumption to fattening rates of surf scoters collected in SE Alaska by modeling the effects of spawn availability on plasma triglycerides. Concentrations of plasma triglycerides are positively correlated with rates of fat deposition, especially over the previous few hours (Ramenofsky 1990, Jenni \& Jenni-Eiermann 1996). Collections of scoters in SE Alaska were of actively feeding birds; however, our capture method in BC is biased toward scoters returning from evening roosting sites where feeding does not occur (Lewis et al. 2005). Thus, we did not conduct these analyses for scoters captured in BC, because levels of plasma triglycerides decline within hours after feeding ceases (Landys et al. 2005).

Scoter counts and characteristics of spawning events. We used a $20 \times$ to $60 \times$ spotting scope to count scoters from the shoreline at spawning areas in Washington. We conducted counts weekly before and throughout the period of spawn availability at 7 spawning areas in 2004, 11 areas in 2005, and 1 area in 2006. Spawning areas included Port Orchard/Port Madison, Quilcene Bay, Port Gamble, Dungeness Bay, Sequim Bay, Discovery Bay, Kilisut Harbor, Holmes Harbor, Port Susan, Fidalgo Bay, and the Birch Bay component of the Cherry Point spawning area (Stick 2005). For each spawning area, scoter surveys were conducted throughout documented locations of past spawn deposition (Stick 2005). For each combination of species $\times$ spawning area $\times$ year, we calculated 2 measures of numerical response to spawn:

Absolute numerical response $=N_{\text {max-spawn }}-N_{\text {pre-spawn }}$

Scaled numerical response

$$
=\left(N_{\text {max-spawn }}-N_{\text {pre-spawn }}\right) /\left(N_{\text {pre-spawn }}+20\right)
$$


where $N_{\text {max-spawn }}$ is the maximum number of scoters observed during spawn availability and $N_{\text {pre-spawn }}$ is the average number observed during the 2 surveys prior to spawn availability. Surf scoters are 2 to 4 times more numerous than white-winged scoters in Puget Sound (D. R. Nysewander unpubl. data). Thus, we used the scaled numerical response to evaluate whether these species respond differently to spawn independent of differences in their local abundances. A factor of 20 was added to $N_{\text {pre-spawn }}$ in the denominator of scaled numerical response to reduce the tendency of this measure to increase when $N_{\text {pre-spawn }}$ is particularly low. For each spawning area, we obtained the biomass of spawning herring, dates of spawn deposition, and number of shoreline meters having spawn from WDFW (K. C. Stick unpubl. data; see Stick 2005 for methods). Herring eggs hatch about 2 wk after deposition (Haegele \& Schweigert 1985), so we estimated the duration of spawn availability for each spawning area as the number of days between the date of spawn initiation and $14 \mathrm{~d}$ after the date on which spawn was last deposited.

Scoter captures and collections. We captured scoters in $\mathrm{BC}$ with decoys and floating mist nets (Kaiser et al. 1995). Captured scoters were transported in small kennels to processing stations on shore. In SE Alaska, we collected scoters with shotguns from small boats. For captured and collected scoters, we determined sex based on plumage characteristics and estimated age class by bursal depth (Mather \& Esler 1999). For all analyses, we included only scoters aged as after-hatchyear (i.e. born before the most recent breeding season). We measured the fresh body mass $( \pm 5 \mathrm{~g})$, wing chord, and diagonal tarsus length $( \pm 1 \mathrm{~mm})$ of each scoter. For analyses of stable isotopes and plasma metabolites, we used a sterile 25 gauge needle to collect $\sim 200 \mu \mathrm{l}$ of blood from the medial metatarsal vein of captured scoters, or $\sim 3 \mathrm{ml}$ from the heart of collected scoters. Blood was placed in heparinized micro-hematocrit capillary tubes or vials and temporarily stored on ice. Plasma and cellular fractions were separated by centrifugation within $12 \mathrm{~h}$ and stored at $-20^{\circ} \mathrm{C}$. For fatty acid analyses, we collected abdominal subcutaneous adipose from scoters. About $100 \mathrm{mg}$ of adipose was stored in liquid nitrogen (and later transferred to $-80^{\circ} \mathrm{C}$ ) or in chloroform with $0.01 \%$ BHT (an antioxidant) at $-20^{\circ} \mathrm{C}$. For captured scoters, we collected adipose using a biopsy method approved by the University of Wyoming Animal Care and Use Committee. Captured scoters were processed and released within $4 \mathrm{~h}$ (unless retained for implantation of radio or satellite transmitters), and collected scoters were dissected within $4 \mathrm{~h}$.

Fatty acid analyses. Lipid was extracted quantitatively from scoter adipose and prey samples (Folch et al. 1957, Iverson et al. 2001), and fatty acid methyl esters (FAME) were prepared from $<100 \mathrm{mg}$ of extracted lipid using $\mathrm{H}_{2} \mathrm{SO}_{4}$ as a catalyst (Wang et al. 2007). Analysis and identification of all FAME were performed in S. J. Iverson's laboratory at Dalhousie University. Temperature-programmed gas chromatography was conducted using either a PerkinElmer Autosystem II capillary gas chromatograph (GC) or a Varian GC equipped with a flame ionization detector and fitted with a flexible fused silica column (30 $\mathrm{m} \times$ $0.25 \mathrm{~mm}$ inside diameter) coated with $50 \%$ cyanopropyl polysiloxan $(0.25 \mu \mathrm{m}$ film thickness, Agilent Technologies, DB-23) and linked to a computerized integration system (PE Nelson Turbochrom 4 software or Varian Galaxie software). Fatty alcohols and dimethylacetals in bivalve plasmalogens were oxidized to free fatty acids using a modified Jones' reagent according to Budge \& Iverson (2003). Three NMI fatty acids were identified according to Budge et al. (2007). Fatty acids are described using the nomenclature $A: B n-X$, where $A$ is the number of carbon atoms, $B$ the number of double bonds, and $X$ the distance from the terminal methyl group to the closest double bond. Fatty acid data were transformed by a natural $\log$ function before statistical tests to meet the assumption of normality, but we report untransformed values as the mean mass percent of total fatty acids $( \pm \mathrm{SE})$.

Stable isotope analyses. For isotope analyses, samples of scoter blood and food items were oven-dried at $60^{\circ} \mathrm{C}$ to constant mass and ground to a homogeneous powder. Lipids were extracted from ground food items by repeated rinses in 2:1 chloroform:methanol. The lipid-free powder was retrieved by evaporating the solution under a fume hood. Blood and food samples $(\sim 0.7 \mathrm{mg})$ were then placed in tin cups for isotopic analyses. Isotope ratios were measured at the University of Wyoming Stable Isotope Facility on a continuous-flow isotope-ratio mass spectrometer (Finnigan Delta+XP) with samples combusted in a Costech elemental analyzer. We included standards in every run to correct raw values obtained from the mass spectrometer. Stable isotope ratios were expressed using standard delta notation $(\delta)$ in parts per thousand $(\%)$ as:

$$
\delta X=\left[\left(R_{\text {sample }} / R_{\text {standard }}\right)-1\right] \times 1000
$$

where $X$ represents ${ }^{15} \mathrm{~N}$ and $R$ represents the ${ }^{15} \mathrm{~N}:{ }^{14} \mathrm{~N}$ ratio. The standard reference material was atmospheric $\mathrm{N}_{2}$. Replicate measurements of internal laboratory standards indicated that the precision of these analyses was $\pm 0.2 \%$. For comparisons with scoter tissues, the $\delta^{15} \mathrm{~N}$ values of foods were increased by $3.1 \%$ to account for trophic enrichment that would occur when scoters consumed these items, as observed in 
whole blood of carnivorous gulls (Hobson \& Clark 1992).

Plasma metabolite analyses. We analyzed concentrations of triglycerides in scoter blood plasma using spectrophotometric assays (Beckman DU-64 Spectrophotometer) and a Sigma Serum Triglyceride Determination Kit (Sigma TR0100). We report true triglyceride values, which we obtained by subtracting free glycerol from the total bound and unbound glycerol.

Data analyses. We conducted statistical analyses using JMP 5.0.1 (SAS 2002), set all significance levels at $\alpha=0.05$, and report all means $( \pm \mathrm{SE})$. For each scoter species, we evaluated the relationship between each of the 2 measures of numerical response and characteristics of spawning events using multiple linear regression with backward selection (variables retained when $\mathrm{p}<0.05)$. For each model, we included observations from all years because the timing and magnitude of individual spawning events often varies substantially among years (Willson \& Womble 2006). We did not detect strong multi-collinearity among spawn variables (all pairwise $|r|<0.65$ ), so initial models for each species and measure of numerical response included year and all 4 spawn variables. For these and other models, we evaluated outliers by consulting plots of residuals and of Mahalanobis distances (Sheskin 2007).

We used ANCOVA to compare body mass among capture and collection periods separately for males and females of each scoter species, with body size as a covariate. For body size, we used the first principal component score of a PCA on the correlation matrix of diagonal tarsus length and wing chord values (Rising \& Somers 1989). Post hoc analyses were conducted on least-squares means of body mass for each period using Tukey's honestly significant difference (HSD) method of adjusting for multiple comparisons. For males and females of each scoter species, we used ANCOVA to evaluate the relationship between body mass and the estimates of spawn consumption based on fatty acids and stable isotopes. We considered 3 additional effects in these models: body size, year, and the interaction between year and the estimate of spawn consumption (when 2 yr of data were available). One-way ANOVA was used to evaluate differences between spawn and invertebrate foods in terms of fatty acid and stable isotope values, between seasons in terms of mean scoter mass at the non-spawn site, and between spawn and non-spawn sites in terms of mean $\delta^{15} \mathrm{~N}$ values of scoter blood cells.

For surf scoters in SE Alaska, we analyzed separately the effects of scoter body mass, sex, collection time, and year on plasma triglycerides, as done by Acevedo Seaman et al. (2006) and Williams et al. (2007); age class (after-hatch-year) and handling time were identi- cal for all birds in these analyses. Significant factors were included as covariates in ANCOVA models used to analyze differences in plasma triglycerides among sites relative to spawn availability. Triglyceride data were transformed using $\log _{10}$ (triglyceride concentration +1 ), which reduced but did not eliminate deviations from the assumption of normality (Shapiro-Wilk test, $\mathrm{p}=0.022$ ). However, general linear models are typically robust to such deviations (Sheskin 2007).

\section{RESULTS}

\section{Numerical response of scoters to spawn}

For white-winged scoters Melanitta fusca in Puget Sound, the absolute numerical response to spawning events increased with increasing biomass of spawning herring Clupea pallasii and decreased with later dates of spawn initiation $\left(F_{2,11}=52.26, \mathrm{p}<0.001, \mathrm{r}^{2}=0.91,1\right.$ outlier removed; $b=0.12 \pm 0.01, t=9.10, \mathrm{p}<0.001$ for biomass; $b=-0.66 \pm 0.21, t=-3.21, \mathrm{p}=0.008$ for date). For surf scoters $M$. perspicillata, the absolute numerical response to spawning also increased with increasing herring biomass, but instead increased with later dates of spawn initiation $\left(F_{2,12}=24.39, \mathrm{p}<0.001, \mathrm{r}^{2}=\right.$ $0.80 ; b=1.26 \pm 0.18, t=6.91, \mathrm{p}<0.001$ for biomass; $b=$ $10.75 \pm 3.43, t=3.14, \mathrm{p}=0.009$ for date). Based on $t$-values, the biomass of spawning herring was more important than other variables to the absolute numerical response of each scoter species (Fig. 2). The scaled numerical response for each species increased with the biomass of spawning herring, and this effect was greater for surf scoters than for white-winged scoters (i.e. $95 \%$ confidence intervals for slope coefficients did not overlap; $b=0.001 \pm 0.0003, F_{1,14}=16.30, \mathrm{p}=0.001$, $\mathrm{r}^{2}=0.54$ for white-winged scoters; $b=0.004 \pm 0.0008$, $F_{1,14}=23.09, \mathrm{p}<0.001, \mathrm{r}^{2}=0.62$ for surf scoters). For white-winged scoters, but not surf scoters, the date of spawn initiation negatively affected the scaled numerical response; however, we omitted this term from the model for white-winged scoters to better enable comparisons between species and because the effect of initiation date was small relative to that of spawn biomass. For each species, effects of shoreline extent of spawn, duration of spawn availability, and year were not significant for either absolute or scaled numerical response.

\section{Effects of spawn consumption on scoter condition}

For white-winged scoters in BC, mean size-corrected body mass did not generally vary through winter and early migration of either year, but increased through 


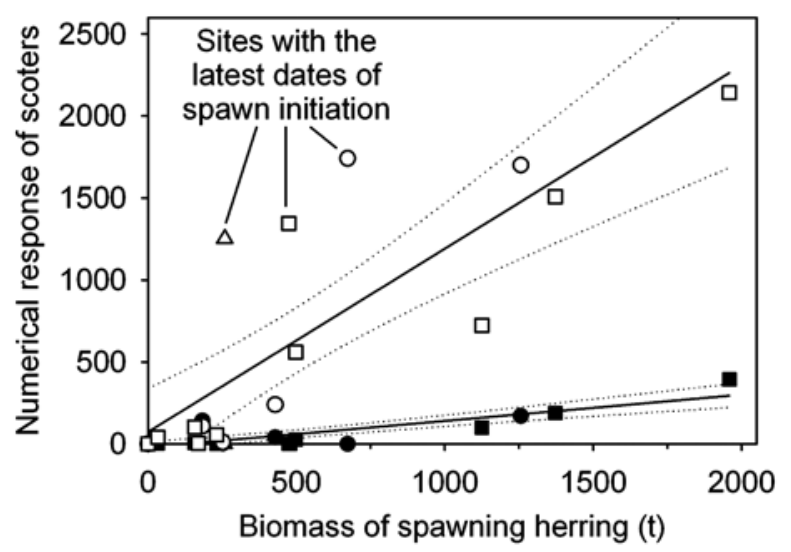

Fig. 2. Melanitta fusca, M. perspicillata. Absolute numerical responses of white-winged scoters (closed symbols) and surf scoters (open symbols) to the biomass of spawning herring Clupea pallasii in Puget Sound, Washington, during 2004 (circles), 2005 (squares), and 2006 (triangle). Regression lines with $95 \%$ confidence intervals are provided for white-winged scoters $\left(b=0.16 \pm 0.02, \mathrm{r}^{2}=0.76, F_{1,17}=52.43, \mathrm{p}<0.001\right)$ and surf scoters $\left(b=1.12 \pm 0.18, \mathrm{r}^{2}=0.70, F_{1,17}=38.90, \mathrm{p}<0.001\right)$. The 3 indicated data points for surf scoters are for Holmes Harbor (2004) and Birch Bay (2005 and 2006), where spawn initiation occurred later (5 to 13 April) than at other spawning areas (16 January to 17 March)

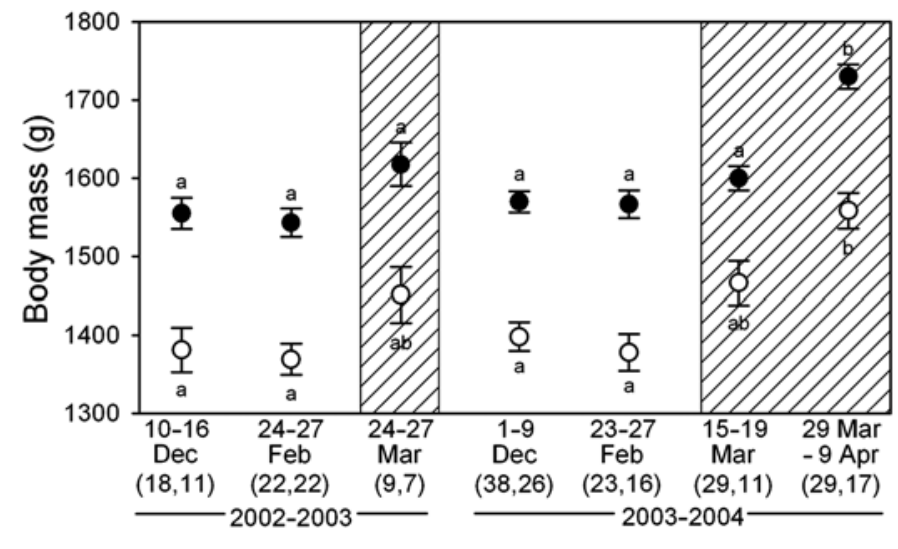

Fig. 3. Melanitta fusca. Size-corrected body mass (leastsquares means $\pm \mathrm{SE}$ ) of white-winged scoter males $(\bullet)$ and females (O) from SE Vancouver Island, BC, from 2002 to 2004. For each sex, means associated with different letters are significantly different (Tukey's HSD test, $\mathrm{p}<0.05$ ). Cross-hatching indicates periods when spawn was locally available, and sample sizes are in parentheses (for males and females, respectively). Very few white-winged scoters were present during the final capture period in 2004 (6 to 9 April), so individuals from the last 2 capture periods were combined for the period 29 March to 9 April. See Table 1 for capture locations by date

Table 3. Melanitta fusca, M. perspicillata. Regressions of scoter body mass on 2 biomarkers of spawn consumption: PC1 scores for 12 fatty acids in scoter adipose and prey (Table 2) and $\delta^{15} \mathrm{~N}$ of scoter blood cells. For each model, we initially included 3 additional effects: body size, year, and interaction between the biomarker and year (when 2 yr of captures or collections were available). Full models include body size only when this effect and the biomarker of spawn consumption were significant. Slope values (b) are for the relationship between the biomarker of spawn consumption and scoter body mass

\begin{tabular}{|c|c|c|c|c|c|c|c|c|}
\hline & \multicolumn{4}{|c|}{ PC1 of 12 fatty acids in scoter adipose } & \multicolumn{4}{|c|}{$\delta^{15} \mathrm{~N}$ of scoter blood cells } \\
\hline & df & $b \pm \mathrm{SE}$ & $r^{2}$ & $\mathrm{p}$ & $\mathrm{df}$ & $b \pm \mathrm{SE}$ & $\mathrm{r}^{2}$ & $\mathrm{p}$ \\
\hline \multicolumn{9}{|l|}{ White-winged scoters, BC } \\
\hline Males $^{\mathrm{a}}$ & 2,27 & $42 \pm 11$ & 0.40 & 0.001 & 1,21 & $59 \pm 23$ & 0.24 & 0.017 \\
\hline Females $^{\mathrm{a}}$ & 1,28 & $52 \pm 10$ & 0.49 & $<0.001$ & 1,20 & $73 \pm 21$ & 0.38 & 0.002 \\
\hline \multicolumn{9}{|l|}{ Surf scoters, BC } \\
\hline Males $2003^{\mathrm{a}, \mathrm{b}}$ & $1,17^{\mathrm{c}}$ & $21 \pm 6$ & 0.39 & 0.004 & - & - & - & - \\
\hline Males, all periods, $2004^{\mathrm{a}, \mathrm{b}}$ & $1,23^{\mathrm{c}}$ & $1 \pm 9$ & $<0.01$ & 0.896 & $2,66^{\mathrm{c}}$ & $12 \pm 6$ & 0.21 & $<0.001$ \\
\hline 15-19 Mar 2004 ${ }^{\mathrm{d}}$ & - & - & - & - & 2,19 & $16 \pm 6$ & 0.43 & 0.005 \\
\hline 29 Mar-2 Apr $2004^{\mathrm{d}}$ & - & - & - & - & 1,20 & $19 \pm 9$ & 0.18 & 0.050 \\
\hline $6-9$ Apr $2004^{\mathrm{d}}$ & - & - & - & - & 1,19 & $-2 \pm 18$ & $<0.01$ & 0.921 \\
\hline Females $^{\mathrm{a}}$ & 1,17 & $15 \pm 11$ & 0.10 & 0.181 & 2,18 & $41 \pm 15$ & 0.47 & 0.003 \\
\hline \multicolumn{9}{|l|}{ Surf scoters, SE Alaska } \\
\hline Males $^{\mathrm{e}}$ & 1,16 & $-12 \pm 12$ & 0.06 & 0.311 & 1,32 & $-19 \pm 10$ & 0.09 & 0.077 \\
\hline Females $^{\mathrm{e}}$ & 1,15 & $4 \pm 13$ & $<0.01$ & 0.791 & 1,40 & $-7 \pm 7$ & 0.02 & 0.336 \\
\hline \multicolumn{9}{|c|}{$\begin{array}{l}{ }^{a} \text { Analyses include scoters captured before spawn availability in February and all scoters captured during spawn availability } \\
\text { in March/April for both PC1 of } 12 \text { fatty acids ( } 2003 \text { and 2004) and } \delta^{15} \mathrm{~N}(2004)\end{array}$} \\
\hline \multicolumn{9}{|c|}{$\begin{array}{l}{ }^{\mathrm{b}} \text { A year effect was significant for the regression of surf scoter body mass on PC1, and thus } 2003 \text { and } 2004 \text { data were analyzec } \\
\text { separately }\end{array}$} \\
\hline \multicolumn{9}{|c|}{${ }^{\mathrm{C}}$ Analysis conducted after removal of 1 or 2 outliers } \\
\hline \multicolumn{9}{|c|}{$\begin{array}{l}\text { dAnalyses include male surf scoters captured only during the respective period of spawn availability; we did not conduct } \\
\text { analyses for separate spawn periods using PC1 because fatty acid data were available for relatively few scoters }\end{array}$} \\
\hline${ }^{\mathrm{e}}$ Analyses include surf scote & s collect & $\mathrm{d}$ in all $\mathrm{SE}$ & aska loc & ns for $\mathrm{PC}$ & and $\delta^{15} \mathrm{~N}$ & 2005 and 2 & & \\
\hline
\end{tabular}




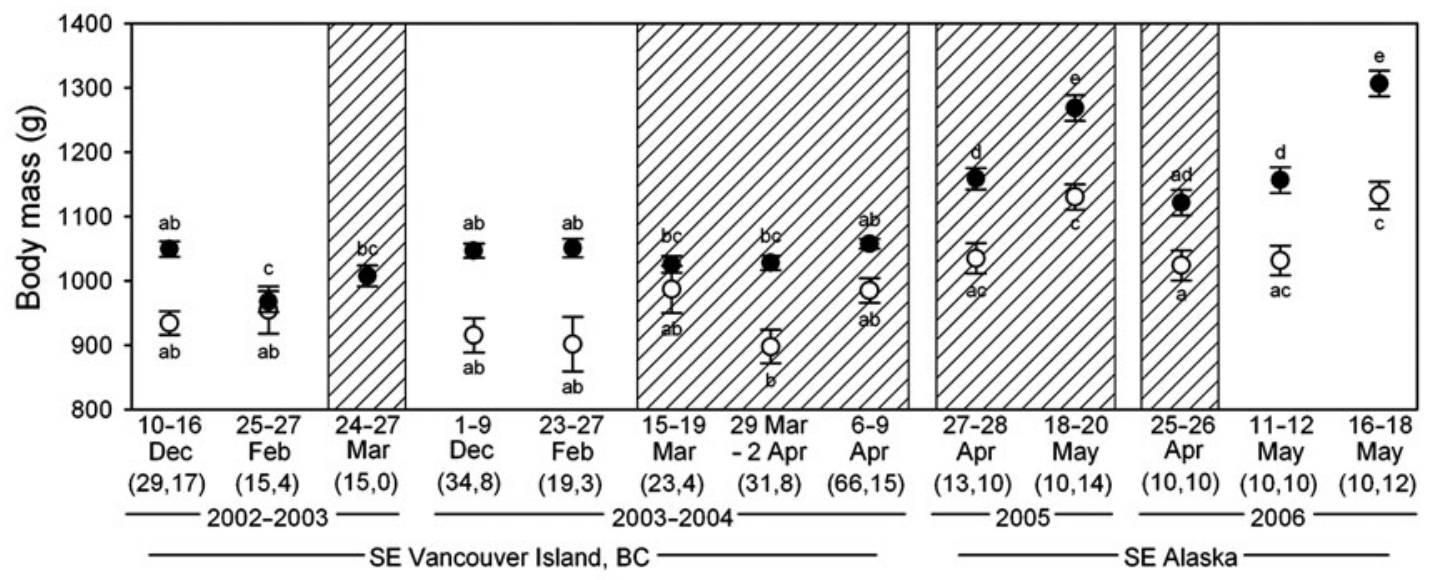

Fig. 4. Melanitta perspicillata. Size-corrected body mass (least-squares means \pm SE) of surf scoters from SE Vancouver Island, BC in 2002 to 2004 and SE Alaska in 2005 to 2006. Collections in SE Alaska during each year occurred at increasingly northern sites (Table 1). Conventions as in Fig. 3

the period of spawn availability in 2004 (Fig. $3 ; F_{7,160}=$ 16.72, $\mathrm{p}<0.001$ for males; $F_{6,103}=8.89, \mathrm{p}<0.001$ for females). For surf scoters in $\mathrm{BC}$, body mass of males declined from December to February in one study year (2002/2003); otherwise, there was no clear change in body mass of either sex through winter and early spring migration when spawn was available (Fig. 4). Mean body mass of surf scoters increased and reached highest values during migration in SE Alaska, in areas both with and without availability of spawn (Fig. 4; $F_{13,272}=31.46, \mathrm{p}<0.001$ for males; $F_{12,102}=11.23, \mathrm{p}<$ 0.001 for females).

Scores from the first principal component (PC1) of the 12 fatty acids examined (Table 2) distinguished spawn from bivalve samples (Fig. $5 \mathrm{a}_{;} F_{1,7}=175.71$, p < 0.001). Mean values among locations of $\delta^{15} \mathrm{~N}$ were greater for spawn than for classes of non-predatory $\left(F_{1,26}=272.56, \mathrm{p}<0.001\right)$ and predatory invertebrates $\left(F_{1,12}=34.19, \mathrm{p}<0.001\right)$, although values overlapped for spawn and predatory invertebrates (Fig. 5b). Thus, PC1 of the 12 fatty acids and $\delta^{15} \mathrm{~N}$ of scoter tissues should be positively correlated with spawn consumption, because predatory invertebrates comprise a minor component of scoter diets (Anderson et al. 2008) and provided that fatty acid and stable isotope signatures do not vary greatly among scoters before spawn consumption (see 'Discussion').

For male and female white-winged scoters in $\mathrm{BC}$, PC1 of 12 fatty acids in their adipose and $\delta^{15} \mathrm{~N}$ of their blood cells were both positively related to body mass (Table 3, Fig. 6). For male surf scoters in BC, body mass was positively related to PC1 in 2003 (but not in 2004) and weakly related to $\delta^{15} \mathrm{~N}$ based on the relatively large sample of scoters from all periods in 2004 (Table 3, Fig. 7). For the 3 periods of spawn availability in BC during $2004, \delta^{15} \mathrm{~N}$ and body mass for male surf scoters
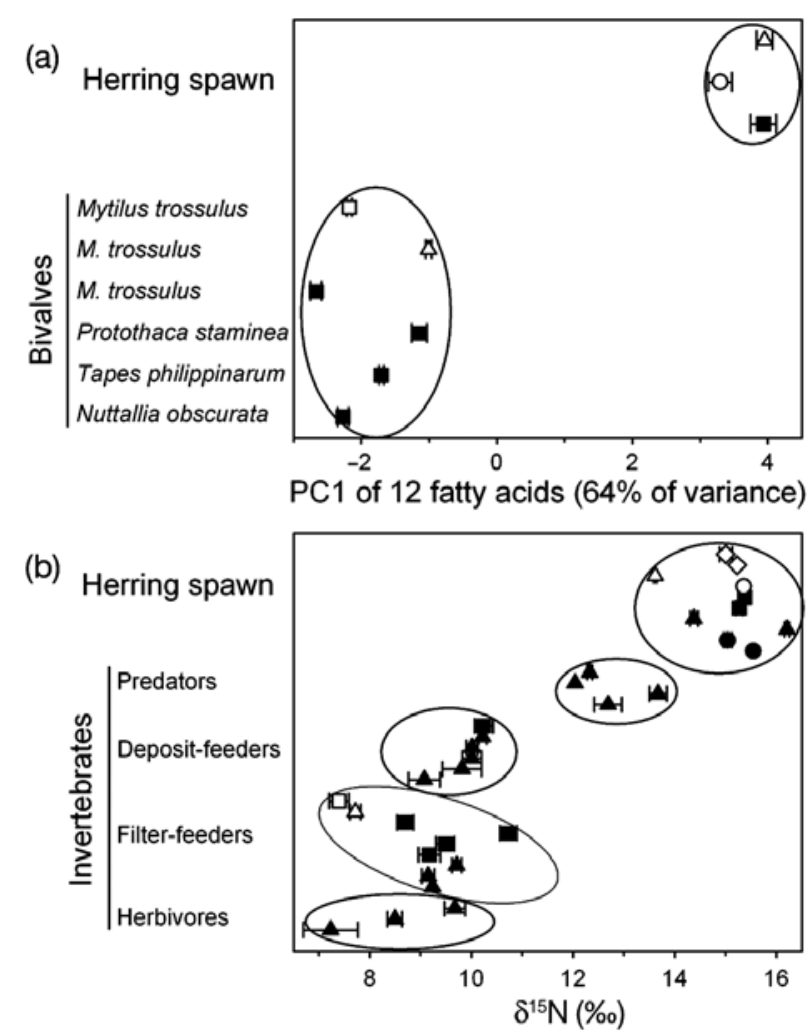

Fig. 5. (a) Mean PC1 scores $( \pm \mathrm{SE})$ for herring spawn and bivalves based on 12 dietary fatty acids in scoter adipose and prey (Table 2). (b) Mean $\delta^{15} \mathrm{~N}$ values $( \pm \mathrm{SE}$ ) for herring spawn and representative invertebrate foods of scoters categorized by feeding mode ( $\mathrm{n}=1$ to 12 samples symbol $^{-1}$ ): predators (Nassariidae, Nephtyidae, Pugettia gracilis), deposit-feeders (Macoma spp., Maldanidae, Ophiuroidea), filter-feeders ( $M Y$ tilus trossulus, Nuttallia obscurata, Protothaca staminea, Tapes philippinarum), and herbivores (Idoteidae). All samples were collected from March through May from 2003 to 2006 in San Francisco Bay $(\bullet)$, Puget Sound $(\boldsymbol{\Delta})$, the Strait of Georgia (घ), and Alaska collection sites including Ketchikan (O), Juneau $(\Delta)$, Haines ( $\square)$, and Prince William Sound $(\diamond)$ 

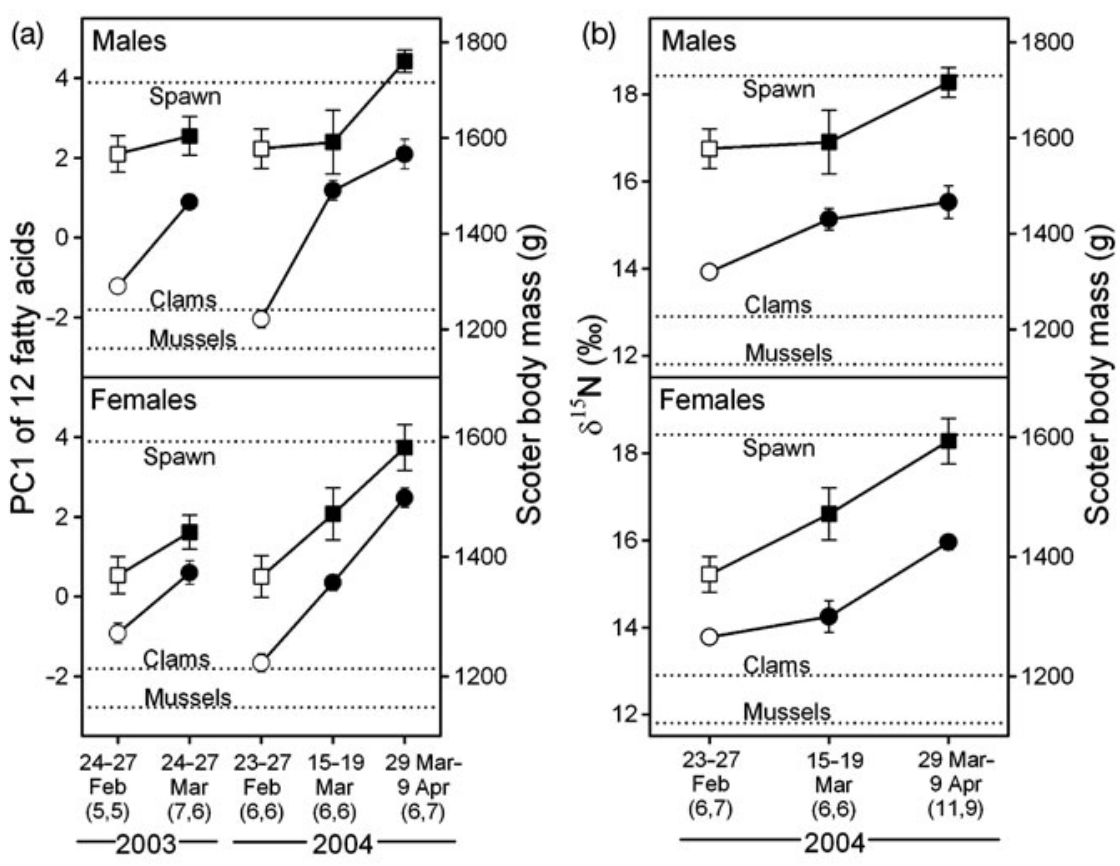

Fig. 6. Melanitta fusca. Seasonal relationship between mean values $( \pm$ SE) of body mass (squares) and estimates of spawn consumption (circles) for sub-samples of white-winged scoters captured in 2003 and 2004 in the Strait of Georgia, BC. Closed symbols represent periods when spawn was locally available, and sample sizes are in parentheses (for males and females, respectively). Estimates of spawn consumption are based on (a) PC1 for 12 fatty acids in white-winged scoter adipose and prey and (b) $\delta^{15} \mathrm{~N}$ of white-winged scoter blood cells (2004 only). Dotted lines in each panel are of mean PC1 and $\delta^{15} \mathrm{~N}$ values for common foods collected in BC $\left(\delta^{15} \mathrm{~N}\right.$ values were increased by $3.1 \%$ to account for trophic enrichment; see Table 2 for sample sizes)

were positively related in the first period $\left(\mathrm{r}^{2}=0.43\right)$, more weakly related in the second period $\left(\mathrm{r}^{2}=0.18\right)$, and unrelated in the final period (Table 3). For female surf scoters in $\mathrm{BC}, \delta^{15} \mathrm{~N}$, but not PC1, of 12 fatty acids (available for females in 2004 only) was positively related to body mass.

At the non-spawn site in $\mathrm{BC}$, mean body mass of male white-winged scoters increased between the first period of captures (2 to 10 March) and the last 2 periods combined (23 March to 23 April; Fig. 8a; $F_{1,27}=$ $9.02, p=0.006)$. However, mean body mass did not change between these periods at the non-spawn site for female white-winged scoters $\left(F_{1,5}=0.28, \mathrm{p}=0.618\right)$, male surf scoters $\left(F_{1,18}=1.96, \mathrm{p}=0.178\right)$, or female surf scoters $\left(F_{1,10}=0.34, \mathrm{p}=0.572\right)$. The percentage increase in mean mass during this period for male white-winged scoters at the non-spawn site $(5.8 \%)$ was similar to the increase at spawn sites during about the same period ( $5.2 \%$ between 23 to 27 February and 15 March to 9 April 2004).

For scoters captured during the period of regional spawn availability in BC during $2004, \delta^{15} \mathrm{~N}$ of blood cells was enriched at spawn sites versus the non- spawn site for white-winged scoters (Fig. 8b; captures for spawn sites from 15 March to 9 April and for the nonspawn site from 23 March to 23 April; $F_{1,19}=13.88, \mathrm{p}=0.001$ for males and $F_{1,16}=12.07, \mathrm{p}=0.003$ for females). Comparing the same periods for surf scoters, $\delta^{15} \mathrm{~N}$ of blood cells did not differ between spawn and non-spawn sites $\left(F_{1,72}=0.21, \mathrm{p}=0.646\right.$ for males; $F_{1,20}=0.39, \mathrm{p}=0.542$ for females). For scoters captured at the non-spawn site during the period of regional spawn availability (23 March to 23 April $2004), \delta^{15} \mathrm{~N}$ of blood cells was greater for surf scoters $(14.7 \pm 0.5 \%$ o) than for white-winged scoters $(13.2 \pm 0.2 \%$, $F_{1,18}=5.57, \mathrm{p}=0.030$, sexes combined for each species).

For surf scoters in SE Alaska, body mass was not related to either PC1 of 12 fatty acids in their adipose or $\delta^{15} \mathrm{~N}$ of their blood cells (Table 3). For SE Alaska sites in which spawn was documented in surf scoter oesophagi plus gizzards (Ketchikan in 2005 and 2006, Juneau in 2005; E. K. Lok unpubl. data), $\delta^{15} \mathrm{~N}$ was not related to surf scoter body mass (a location effect was significant for each sex, but $\mathrm{p}>0.21$ for each sex in each location). Fatty acid data were available for very few surf scoters in SE Alaska, so we did not analyze by site the relationship between PC1 and body mass.

Plasma triglycerides for surf scoters in SE Alaska were not related to body mass, sex, or collection time (all p >0.08), but plasma triglycerides were greater in 2006 than in $2005\left(F_{1,53}=7.76, \mathrm{p}=0.007\right.$, excluding samples from Haines, which were collected in 2006 only). Thus, we did not control for effects of body mass, sex, or collection time, and did not pool triglyceride data for 2005 and 2006. Plasma triglycerides differed among sites in SE Alaska, with greater triglyceride concentrations in surf scoters collected at sites lacking spawn $\left(F_{4,65}=9.80, \mathrm{p}<0.001 ;\right.$ Fig. 9$)$.

\section{DISCUSSION}

Diverse animals aggregate to consume spawning herring and their spawn, larvae, and juvenile growth forms (Høines \& Bergstad 1999, Willson \& Womble 2006). Such aggregations suggest that spawning herring are a valuable resource within the annual cycle of many marine predators. However, past studies had not 

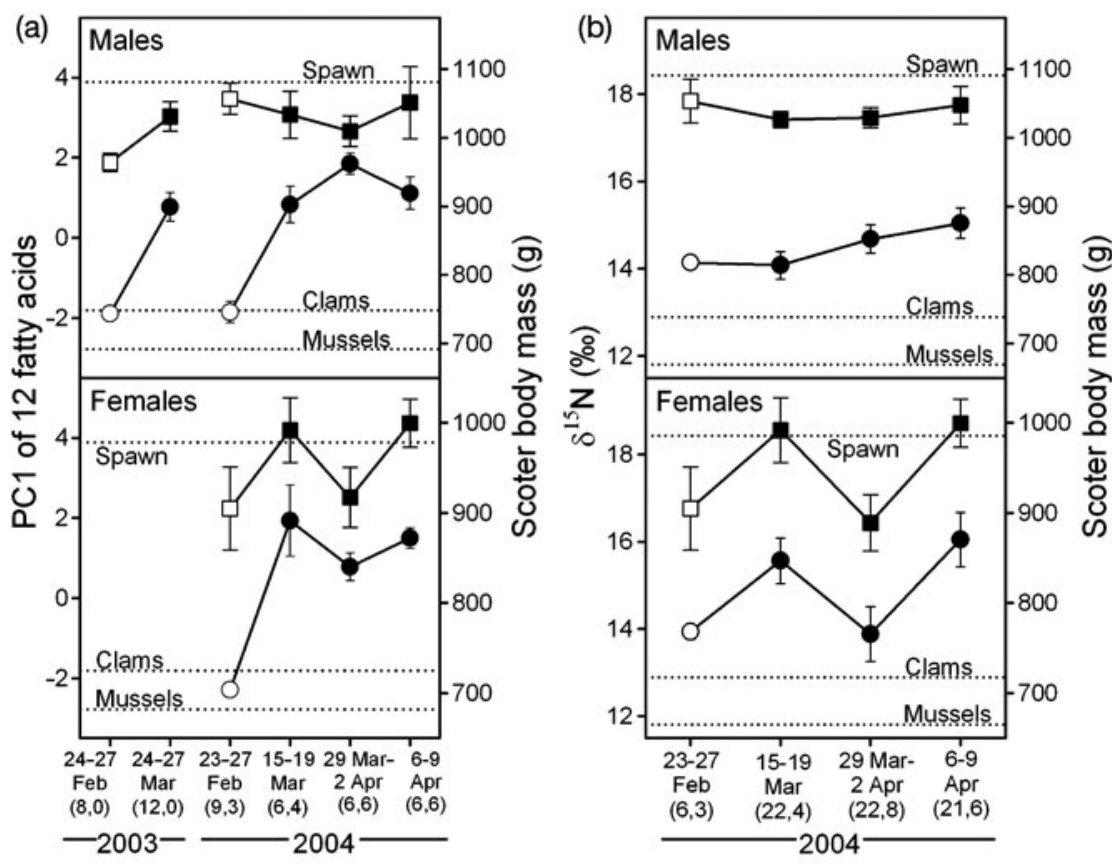

Fig. 7. Melanitta perspicillata. Seasonal relationship between mean values $( \pm \mathrm{SE})$ of body mass (squares) and estimates of spawn consumption (circles) for sub-samples of surf scoters captured in 2003 and 2004 in the Strait of Georgia, BC. Female surf scoters are not reported for 2003 because very few were captured. Conventions as in Fig. 6 serves. The much greater numerical response of surf scoters to spawning events also indicates that spawn is more important to them. However, there was no correlation between biomarkers of spawn consumption and body mass of surf scoters during late spring in BC or SE Alaska. We suggest that this lack of correlation resulted from (1) aggregation on spawning grounds of non-local migrants with variable diet signatures and body masses and (2) seasonal increases in fattening rates that may be partly unrelated to food type.

\section{Numerical response of scoters to spawn}

Surf scoters are 2 to 4 times more numerous than white-winged scoters in Puget Sound (D. R. Nysewander unpubl. data), which likely contributed to the relatively greater numbers of surf scoters observed at spawning areas there. However, after accounting assessed effects of specific characteristics of spawning events on seasonal distributions of predators, or the contribution of spawn to predator condition. We coupled both types of analyses to examine the importance of herring spawn to 2 closely related and declining species of sea duck. Both white-winged scoters Melanitta fusca and surf scoters $M$. perspicillata gained body mass while consuming spawn during late winter to

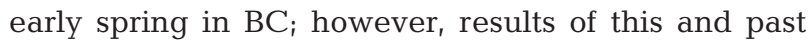
studies indicate that body reserves decline over winter to a greater extent in surf scoters (Henny et al. 1991, Anderson \& Lovvorn 2008, E. M. Anderson unpubl. data). Thus, while spawn appears to be a preferred food for both species, in some years it may be relatively more important to surf scoters for replacing depleted re-

Fig. 8. Melanitta fusca, M. perspicillata. (a) Comparisons of mean body mass $( \pm \mathrm{SE})$ for scoters captured at a non-spawn site in BC from 2 to 10 March 2004 (O) versus 23 March to 23 April 2004 ( availability in other locations in BC). (b) For the period of spawn availability in $\mathrm{BC}$, comparisons of mean $\delta^{15} \mathrm{~N}$ of blood cells $( \pm \mathrm{SE})$ between scoters captured at a non-spawn site (23 March to 23 April 2004, O) and at spawn sites (15 March to 9 April 2004, ๑). Dotted lines are of mean $\delta^{15} \mathrm{~N}$ values (increased by $3.1 \%$ to account for trophic enrichment) for common foods collected in BC. Sample sizes are in parentheses. * Significant differences $(p<0.01)$ between paired means
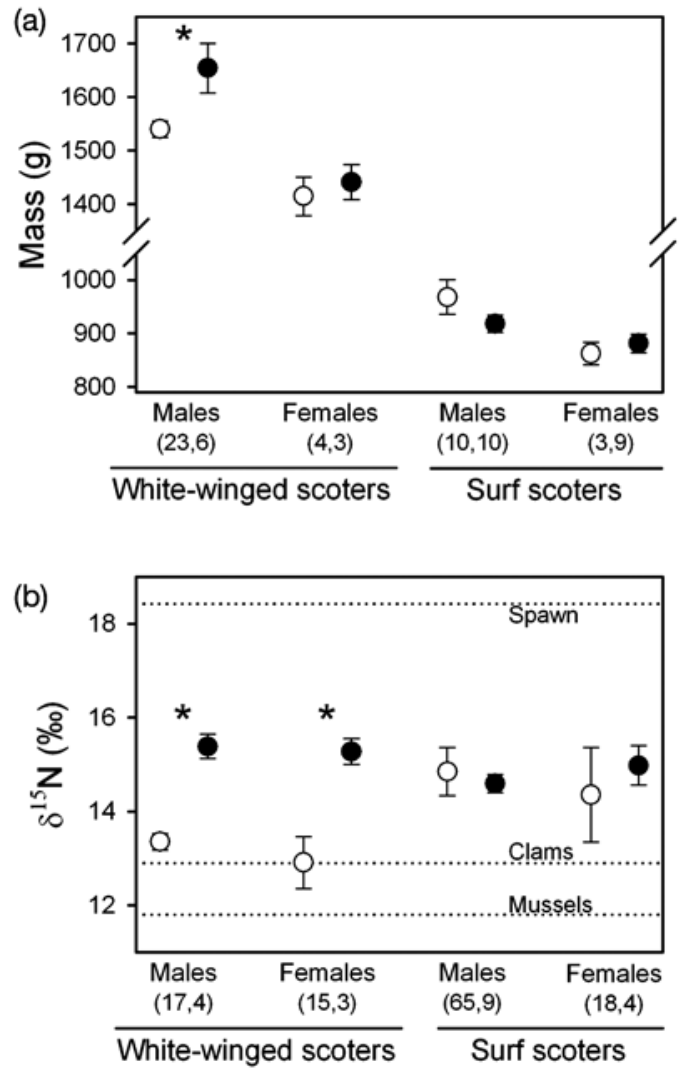


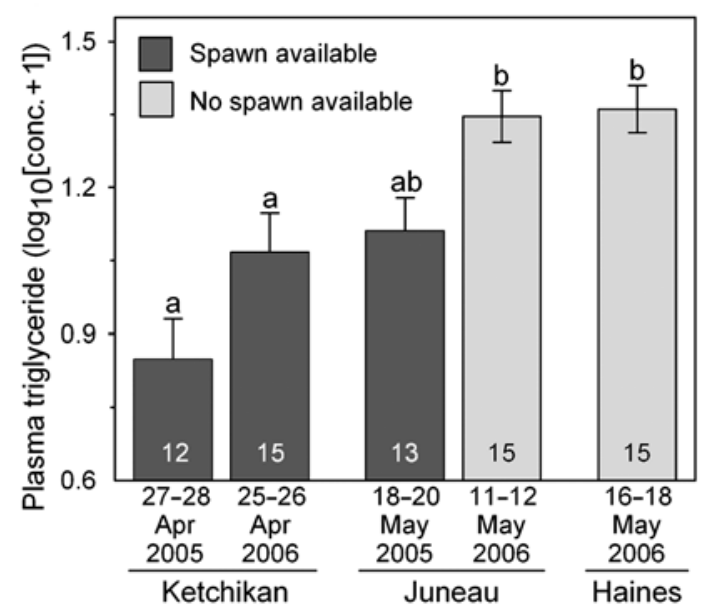

Fig. 9. Melanitta perspicillata. Mean concentrations of plasma triglycerides $( \pm \mathrm{SE})$ for surf scoters collected in SE Alaska during spring migration in 2005 and 2006 (numbers in bars are sample sizes). Means associated with different letters differed significantly (Tukey's HSD test, $\mathrm{p}<0.05$ ), and collections during each year occurred at increasingly northern sites (Table 1)

for differences in local abundances of these species, surf scoters still showed a 4 -fold greater numerical response than white-winged scoters to the biomass of spawning herring. Telemetry studies near our capture sites on Vancouver Island, BC, indicated that surf scoters also traveled longer mean distances to spawning areas $(17 \mathrm{~km})$ than did white-winged scoters $(10 \mathrm{~km}$; Lok et al. 2008).

The numerical response of white-winged scoters to spawning events in Puget Sound decreased slightly with later dates of spawn initiation. This pattern suggests that spawn does not increase in importance for white-winged scoters during migration. Conversely, the increasing numerical response of surf scoters to spawning events later in spring is likely due to aggregations of migrants from farther south (Lok et al. 2008). We observed $<3000$ surf scoters at each spawning area in Washington from mid-January to mid-April. However, far greater aggregations occur at spawning events later during spring migration (late April to May), particularly for those in SE Alaska, where numbers of surf scoters may exceed 75000 at a single spawning area (Lok 2008). Such aggregations, together with the large number of herring spawning areas along the Pacific coast, suggest that a substantial fraction of surf scoters consume spawn each year.

Most spawning events in Puget Sound occurred between January and March, a period before spring migration, when scoters move to spawning sites that are relatively close to their winter foraging areas (mostly $<30$ km; Lok et al. 2008). For spawning events later in spring migration, when surf scoters are more mobile (Lok 2008), their numerical response may increase with spawning duration because of continuing arrival of migrants from more southerly wintering grounds. The extent of spawn along shorelines did not affect the numerical response of scoters, possibly because scoter foraging profitability may be influenced by spawn density more than extent-spawn density was unrelated to shoreline extent of spawn and often varied within a spawning area (K. C. Stick unpubl. data).

\section{Effects of spawn consumption on scoter condition}

Based on correlations between body mass and biomarkers of diet, both scoter species gained mass while consuming spawn during late winter and early spring in BC. Male white-winged scoters gained mass during this period even at non-spawn sites, suggesting that spawn is not a uniquely important food to them. In contrast, surf scoters may depend strongly on spawn in years when body reserves have declined over winterin 2003, but not 2004, body mass in males declined between December and February, and subsequent mass gains were correlated with biomarkers of spawn consumption. However, this correlation weakened throughout the period of spawn availability, until there was no correlation during late spring migration in BC and SE Alaska. This decreased correlation probably did not result from decreased spawn consumption because both feeding behaviour and fecal contents suggest that the birds were mainly eating spawn (D. Esler unpubl. data). Rather, the decreased correlation of body mass with spawn biomarkers likely reflected the greater diversity of migration histories among the much higher numbers of surf scoters attracted to spawning sites.

For surf scoters, continued influx to spawning sites from many distant wintering areas should increasingly obscure relationships between body mass and spawn consumption. Body mass will differ among birds within a site during migration, owing to varying quality of feeding opportunities encountered earlier in migration and the extent of reserve-depleting movements (Arzel et al. 2006, Newton 2006). Also, tissue fatty acids and stable isotopes typically vary among birds from different foraging areas and regions (Hobson 1999, Iverson et al. 2007, Wang et al. 2007). Increased variation in diet biomarkers among individual surf scoters in late winter and spring could also be related to increases in the diversity of food items they consume as winter progresses (Anderson et al. 2008). For white-winged scoters, the lower numerical response to spawn and greater seasonal stability in diet reduce these complications. 
For white-winged scoters captured during the later period at the non-spawn site, values of $\delta^{15} \mathrm{~N}$ in their blood cells indicate that they probably had not eaten appreciable amounts of spawn at other areas in BC or Washington. (The $\delta^{15} \mathrm{~N}$ of blood cells integrates diet over a period of several weeks to months; Hobson 1999.) Thus, for male white-winged scoters, similar increase in body mass at both the non-spawn site $(5.8 \%)$ and spawn sites $(5.2 \%)$ indicates that their mass gains did not depend on spawn consumption. For female white-winged scoters, body mass increased at spawn sites but not at the non-spawn site, suggesting that spawn was important to mass gains. For surf scoters, $\delta^{15} \mathrm{~N}$ of blood cells and their greater numerical response to spawn suggest that captures at both spawn and non-spawn sites included birds from other wintering areas that may have consumed spawn before their arrival. Thus, comparisons of body mass at spawn versus non-spawn sites are not appropriate for assessing whether reserves of surf scoters increased independently of spawn consumption. Also, results from the non-spawn site should be viewed with caution given that this site had limited sample sizes, was from a single wintering area, and did not provide data on body mass changes throughout spring migration.

For surf scoters, mean body mass and plasma triglyceride levels increased during late spring migration in SE Alaska. Given the similarity of mass gains at sites with spawn in 2005 and sites lacking spawn in 2006 (Fig. 4), these increases probably did not result from differences in spawn availability among our capture and collection sites. During each year of our sampling, the biomass of spawning herring was about $30000 \mathrm{t}$ near our capture sites in $\mathrm{BC},<1100 \mathrm{t}$ in Behm Canal near Ketchikan, <350 t in Berner's Bay near Juneau, and $0 \mathrm{t}$ in Chilkoot Inlet near Haines (Davidson et al. 2005, 2006, Pritchett et al. 2007, DFO 2008). However, we do not know whether spawn consumption in areas between our BC and SE Alaska sites might have affected mass gains for surf scoters. Importantly, much spawn is available along coastal BC north of Vancouver Island and near Sitka in SE Alaska (>50 $000 \mathrm{t} \mathrm{yr}^{-1}$ for each region in 2005 and 2006; Davidson et al. 2005, 2006, DFO 2008).

For birds during spring migration, mass gains are typically associated with increased feeding effort, greater consumption of energy-rich foods, or upregulation of the digestive system (Biebach 1996, McWilliams \& Karasov 2001). Thus, for surf scoters, increased body mass and plasma triglycerides at areas progressively farther north in SE Alaska may have been driven by endogenous signals (Williams et al. 2007). Even so, effects of endogenous regulation and food availability are probably not mutually exclusive. For waterfowl, food availability can strongly affect migration timing and routes (Arzel et al. 2006). Surf scoters aggregate to consume spawn whenever it is available (Lok 2008), indicating its importance to energy gains regardless of physiological changes that facilitate fattening at a given food intake. Also, levels of plasma triglycerides may underestimate effects of spawn on scoter fattening; scoters significantly reduce their time spent foraging when eating spawn versus other foods (Lewis et al. 2007b), and levels of plasma triglycerides decline within hours after feeding ceases (Landys et al. 2005). For scoters, this lower foraging effort and avoiding costs of processing shell matter (scoters ingest whole bivalves) are likely more important benefits of spawn than its energy content; energy density is no greater for spawn than for the soft tissue of bivalves commonly consumed by scoters (E. M. Anderson unpubl. data).

\section{Possible reasons for differences between white-winged and surf scoters}

Past results reveal differences between scoter species that may underlie the greater numerical response of surf scoters to herring spawn. Surf scoters appear to lose body reserves over winter to a greater extent than white-winged scoters (Henny et al. 1991, Anderson \& Lovvorn 2008, present study, E. M. Anderson unpubl. data). Differences among years and wintering sites in the magnitude of such declines for surf scoters suggest that their reserves are affected at least partly by environmental conditions (Lovvorn 1994) versus endogenous regulation (Barboza \& Jorde 2002). Compared to the broader size range of bivalves consumed by whitewinged scoters, surf scoters are restricted to smaller bivalves, which are eaten by both scoter species in early winter (Anderson et al. 2008). Thus, depletion of bivalves over winter by scoters and other sea ducks (Hamilton 2000, Kirk et al. 2007) may have a greater impact on the ability of surf scoters to meet their energy demands. For surf scoters, seasonal declines in both body reserves and availability of smaller bivalves likely contribute to their greater tendency to consume non-bivalve foods that become available in late winter and spring, such as herring spawn, commercial grain, reproducing polychaetes, eelgrass epifauna, and invertebrates made available by the feeding activities of gray whales Eschrichtius robustus (Henny et al. 1991, Lacroix et al. 2005, Anderson et al. 2008, Anderson \& Lovvorn 2008). Compared to white-winged scoters, surf scoters also appear more likely to migrate farther north along the Pacific coast before turning inland to breeding areas in the boreal forest (Lok 2008). The smaller size and lower nutrient reserves of surf scoters may not be adequate to withstand more variable timing of food 
availability at inland wetlands compared to the relative predictability of marine foods such as herring spawn.

\section{Herring declines and protection of spawning areas}

Declines in many herring populations are well-documented. Of the 19 spawning stocks in Puget Sound, 6 are considered depressed (abundance well below the long-term mean) and the status of 3 is considered critical (abundance low enough that permanent damage is already likely) (Stick 2005). In Lynn Canal in SE Alaska and at Cherry Point in Puget Sound, once prominent spawning stocks of herring have declined by 80 to $90 \%$ in biomass and in geographic range from the early 1970 s to the mid-2000s (National Marine Fisheries Service 2005, Stick 2005). In the Strait of Georgia, BC, the annual duration and geographic range of spawning activity have declined substantially since about the 1970s (Hay \& McCarter 1999). Factors contributing to declines in specific stocks include intrinsic population processes (Lasker 1985), overfishing (Varpe et al. 2005), disease (Marty et al. 2003), changes in climate (Toresen \& Østvedt 2000), and local environmental conditions (Williams \& Quinn 2000). It is often difficult to identify the relative contribution of these factors to the decline in a particular herring stock (e.g. Carls et al. 2002). Regardless, declines in spawning biomass and in the spatial and temporal extents of spawning activity have likely reduced the availability of the herring resource to a range of predators (Willson \& Womble 2006).

Developing management strategies to preserve herring stocks is a critical first step toward protecting spawning events for predators. Management of herring is complicated by their substantial seasonal movements and the diversity of factors that affect their populations, many of which are not local to spawning areas. Nonetheless, habitat degradation is a primary cause of declines in many coastal marine species (Kappel 2005), and further protections for eelgrass and other spawning habitats are likely critical to herring conservation. Indeed, legislative mandate in the United States requires sustaining herring populations, in part by protecting their spawning habitat (Magnuson-Stevens Fishery Conservation and Management Act, amended 2007). In addition to year-round protection measures for spawning habitat, time-area closures may be needed to minimize the effects of human disturbance on predators that aggregate at spawning areas. For instance, vessel traffic has sub-lethal effects on waterfowl, including increases in the rate of energetically costly movements and reductions in energy intake (Béchet et al. 2004).

Although the importance of spawning events to highly mobile predators other than scoters has been less-intensively studied, we suggest that protection of spawning areas will benefit predators ranging from marine birds and fish to whales (Willson \& Womble 2006). Additional research is needed to evaluate whether the herring resource is essential to the population processes of surf scoters and other predators observed at spawning areas or is merely the most profitable among a range of viable foods. Nonetheless, 2 factors suggest that spawning areas should receive additional protection. First, existing management does not appear adequate to preserve spawning habitat. Second, many of the predators observed at spawning sites are declining in numbers and are vulnerable to site-specific impacts, such as bycatch and contaminant exposure. Additional protection measures for spawning areas may be achieved through their designation within existing frameworks. Canada's Oceans Act protects 'ecologically and biologically significant areas,' defined as sites where marine organisms are highly aggregated during an important part of the annual cycle (DFO 2004). In the United States, spawning grounds should be considered for designation as marine protected areas (MPAs) under Executive Order 13158, which promotes a scientifically based system of MPAs to enhance ecological and economic sustainability of marine environments (President, Proclamation 2000).

Acknowledgements. C. Fort, D. Hay, R. Merizon, and D. Watters provided spawn samples and invaluable information about herring spawning events. E. Lok, D. Nysewander, J. Evenson, and S. Wainwright-De la Cruz provided information on scoter distributions and movements. C. Martínez del Rio provided helpful advice with sample preparation and analyses. S. Iverson, S. Lang, and S. Al-Shaghay provided guidance with preparation of fatty acids. K. Gorman provided assistance with laboratory analyses. Field assistance was provided by B. Bartzen, T. Bowman, R. Corcoran, S. Coulter, R. Dickson, E. Drew, A. Gall, G. Grigg, S. Iverson, M. Kirk, D. Lacroix, T. Lewis, R. Lis, E. Lok, M. McAdie, A. McLean, A. Myers, D. Rizzolo, E. Sellentin, S. Wallace, M. Wilson, and R. Žydelis. Scoters were captured in BC with Environment Canada permits (Nos. 59-03-0360 and 59-04-0140), and were collected in Alaska with permits from the US Fish and Wildlife Service (No. MB103788-0) and the Alaska Department of Fish and Game (Nos. 05-077 and 06-061). The present study was funded by the SeaDoc Society of the Wildlife Health Center at the UC Davis School of Veterinary Medicine (No. K00443119), the Sea Duck Joint Venture (No. 701816M183), the US Fish and Wildlife Service Western Washington Fish and Wildlife Office (No. 13410-5-J008), the National Science Foundation Office of Polar Programs (Nos. OPP-9813979 and ARC-0454454 to J.R.L.), and fellowships to E.M.A. from the National Oceanic and Atmospheric Administration National Estuarine Research Reserve System (Graduate Research Fellowship No. NA03NOS4200048), the Wyoming National Aeronautics and Space Administration Space Grant Consortium, Wyoming NASA EPSCoR (No. NCC5-578), the National Science Foundation GK12 Program (No. DGE-0538642), and the University of Wyoming Robert and Carol Berry Center for Natural History and Conservation. 


\section{LITERATURE CITED}

Acevedo Seaman DA, Guglielmo DG, Elner RW, Williams TD (2006) Landscape-scale physiology: site differences in refueling rates indicated by plasma metabolite analysis in free-living migratory sandpipers. Auk 123:563-574

> Anderson EM, Lovvorn JR (2008) Gray whales may increase feeding opportunities for avian benthivores. Mar Ecol Prog Ser 360:291-296

Anderson EM, Lovvorn JR, Wilson MT (2008) Reevaluating marine diets of surf and white-winged scoters: interspecific differences and the importance of soft-bodied prey. Condor 110:285-295

Anteau MJ, Afton AD (2004) Nutrient reserves of lesser scaup (Aythya affinis) during spring migration in the Mississippi flyway: a test of the spring condition hypothesis. Auk 121: 917-929

Arzel C, Elmberg J, Guillemain M (2006) Ecology of springmigrating Anatidae: a review. J Ornithol 147:167-184

Baker AJ, González PM, Piersma T, Niles LJ and others (2004) Rapid population decline in red knots: fitness consequences of decreased refuelling rates and late arrival in Delaware Bay. Proc R Soc Lond B Biol Sci 271:875-882

Barboza PS, Jorde DG (2002) Intermittent fasting during winter and spring affects body composition and reproduction of a migratory duck. J Comp Physiol B 172:419-434

Béchet A, Giroux JF, Gauthier G (2004) The effects of disturbance on behaviour, habitat use and energy of spring staging snow geese. J Appl Ecol 41:689-700

Biebach H (1996) Energetics of winter and migratory fattening. In: Carey C (ed) Avian energetics and nutritional ecology. Chapman \& Hall, New York, p 280-323

Bishop MA, Green PG (2001) Predation on Pacific herring (Clupea pallasi) spawn by birds in Prince William Sound, Alaska. Fish Oceanogr 10(Suppl 1):149-158

Budge SM, Iverson SJ (2003) Quantitative analysis of fatty acid precursors in marine samples: direct conversion of wax ester alcohols and dimethylacetals to FAMEs. J Lipid Res 44:1802-1807

Budge SM, Springer AM, Iverson SJ, Sheffield G (2007) Fatty acid biomarkers reveal niche separation in an Arctic benthic food web. Mar Ecol Prog Ser 336:305-309

Carls MG, Marty GD, Hose JE (2002) Synthesis of the toxicological impacts of the Exxon Valdez oil spill on Pacific herring (Clupea pallasi) in Prince William Sound, Alaska, USA Can J Fish Aquat Sci 59:153-172

Cherel Y, Hobson KA, Bailleul F, Groscolas R (2005) Nutrition, physiology, and stable isotopes: new information from fasting and molting penguins. Ecology 86:2881-2888

Dahl TM, Falk-Petersen S, Gabrielsen GW, Sargent JR, Hop H, Millar RM (2003) Lipids and stable isotopes in common eider, black-legged kittiwake and northern fulmar: a trophic study from an Arctic fjord. Mar Ecol Prog Ser 256:257-269

Davidson W, Bergmann W, Doherty P, Monagle K, Gordon D (2005) Southeast Alaska sac roe herring fishery, 2005. Report No. 05-05, Alaska Department of Fish and Game Fishery Management, Anchorage, AK

Davidson W, Bergmann W, Doherty P, Monagle K, Gordon D (2006) Southeast Alaska sac roe herring fishery, 2006. Report No. 06-07, Alaska Department of Fish and Game Fishery Management, Anchorage, AK

DFO (Department of Fisheries and Oceans) (2004) Identification of ecologically and biologically significant areas. Scientific Advisory Secretariat ecosystem status report 2004/2006, Department of Fisheries and Oceans Canada, Ottawa

DFO (Department of Fisheries and Oceans) (2008) Pacific herring geographic bulletin. Available at: www.pac.dfompo.gc.ca/sci/herring/herspawn/pages/sitemap_e.htm (accessed on 1 October 2008)

Dickson DL, Gilchrist HG (2002) Status of marine birds of the southeastern Beaufort Sea. Arctic 55(Suppl 1):46-58

> Folch J, Lees M, Sloane-Stanley GH (1957) A simple method for the isolation and purification of total lipids from animal tissues. J Biol Chem 226:497-509

Gauthier G, Bêty J, Hobson KA (2003) Are greater snow geese capital breeders? New evidence from a stableisotope model. Ecology 84:3250-3264

Haegele CW (1993) Seabird predation of Pacific herring, Clupea pallasi, spawn in British Columbia. Can Field Nat 107: 73-82

Haegele CW, Schweigert JF (1985) Distribution and characteristics of herring spawning grounds and description of spawning behavior. Can J Fish Aquat Sci 42(Suppl 1): 39-55

Hamilton DJ (2000) Direct and indirect effects of predation by common eiders and abiotic disturbance in an intertidal community. Ecol Monogr 70:21-43

Hay DE, McCarter PB (1999) Distribution and timing of herring spawning in British Columbia. Canadian Stock Assessment Secretariat Research Document 99/14, Fisheries and Oceans Canada, Nanaimo

Hemminga MA, Duarte CM (2000) Seagrass ecology. Cambridge University Press, New York

Henny CJ, Blus LJ, Grove RA, Thompson SP (1991) Accumulation of trace elements and organochlorines by surf scoters wintering in the Pacific Northwest. Northwest Nat 72:43-60

Hinrichsen D (1998) Coastal waters of the world: trends, threats, and strategies. Island Press, Washington, DC

> Hobson KA (1999) Tracing origins and migration of wildlife using stable isotopes: a review. Oecologia 120:314-326

Hobson KA, Clark RG (1992) Assessing avian diets using stable isotopes. II. Factors influencing diet-tissue fractionation. Condor 94:189-197

- Hobson KA, Alisauskas RT, Clark RG (1993) Stable-nitrogen isotope enrichment in avian tissues due to fasting and nutritional stress: implications for isotopic analyses of diet. Condor 95:388-394

> Hobson KA, Thompson JE, Evans MR, Boyd S (2005) Tracing nutrient allocation to reproduction in Barrow's goldeneye. J Wildl Manage 69:1221-1228

Hodges JI, King JG, Conant B, Hanson HA (1996) Aerial surveys of waterbirds in Alaska 1957-94: population trends and observer variability. US Department of the Interior. Natl Biol Serv Inf Technol Rep 4

Høines ÅS, Bergstad OA (1999) Resource sharing among cod, haddock, saithe and pollock on a herring spawning ground. J Fish Biol 55:1233-1257

Iverson SJ, Lang SLC, Cooper MH (2001) Comparison of the Bligh and Dyer and Folch methods for total lipid determination in a broad range of marine tissue. Lipids 36: 1283-1287

> Iverson SJ, Field C, Bowen WD, Blanchard W (2004) Quantitative fatty acid signature analyses: a new method of estimating predator diets. Ecol Monogr 74:211-235

Iverson SJ, Springer AM, Kitaysky AS (2007) Seabirds as indicators of food web structure and ecosystem variability: qualitative and quantitative diet analyses using fatty acids. Mar Ecol Prog Ser 352:235-244

> Jenni L, Jenni-Eiermann S (1996) Metabolic responses to diurnal feeding patterns during the postbreeding, moulting and migratory periods in passerine birds. Funct Ecol 10:73-80 
Kaiser GW, Derocher AE, Crawford S, Gill MJ, Manley IA (1995) A capture technique for marbled murrelets in coastal inlets. J Field Ornithol 66:321-333

Kappel CV (2005) Losing pieces of the puzzle: threats to marine, estuarine, and diadromous species. Front Ecol Environ 3:275-282

Kirk M, Esler D, Boyd WS (2007) Morphology and density of mussels on natural and aquaculture structure habitats: implications for sea duck predators. Mar Ecol Prog Ser 346:179-187

Lacroix DL, Boyd S, Esler D, Kirk M, Lewis T, Lipovsky S (2005) Surf scoters Melanitta perspicillata aggregate in association with ephemerally abundant polychaetes. Mar Ornithol 33:61-63

Landys MM, Piersma T, Guglielmo CG, Jukema J, Ramenofsky M, Wingfield JC (2005) Metabolic profile of longdistance migratory flight and stopover in a shorebird. Proc R Soc Lond B Biol Sci 272:295-302

Lasker R (1985) What limits clupeoid production? Can J Fish Aquat Sci 42(Suppl 1):31-38

> Lewis TL, Esler D, Boyd WS, Žydelis R (2005) Nocturnal foraging behavior of wintering surf scoters and whitewinged scoters. Condor 107:637-647

Lewis TL, Esler D, Boyd WS (2007a) Effects of predation by sea ducks on clam abundance in soft-bottom intertidal habitats. Mar Ecol Prog Ser 329:131-144

Lewis TL, Esler D, Boyd WS (2007b) Foraging behaviors of surf scoters and white-winged scoters during spawning of Pacific herring. Condor 109:216-222

Lok EK (2008) Site use and migration of scoters (Melanitta spp.) in relation to the spawning of Pacific herring (Clupea pallasi). MS thesis, Simon Fraser University, Burnaby

Lok EK, Kirk M, Esler D, Boyd WS (2008) Movements of premigratory surf and white-winged scoters in response to herring spawn. Waterbirds 31:385-393

Louzao M, Hyrenbach KD, Arcos JM, Abelló P, de Sola LG, Oro D (2006) Oceanographic habitat of an endangered Mediterranean procellariiform: implications for marine protected areas. Ecol Appl 16:1683-1695

Lovvorn JR (1994) Nutrient reserves, probability of cold spells and the question of reserve regulation in wintering canvasbacks. J Anim Ecol 63:11-23

Marty GD, Quinn TJ II, Carpenter G, Meyers TR, Willits NH (2003) Role of disease in abundance of a Pacific herring (Clupea pallasi) population. Can J Fish Aquat Sci 60: 1258-1265

Mather DD, Esler D (1999) Evaluation of bursal depth as an indicator of age class of harlequin ducks. J Field Ornithol 70:200-205

McWilliams SR, Karasov WH (2001) Phenotypic flexibility in digestive system structure and function in migratory birds and its ecological significance. Comp Biochem Physiol A 128:579-593

Munro JA, Clemens WA (1931) Water fowl in relation to the spawning of herring in British Columbia. Bull Biol Board Can 17:1-46

National Marine Fisheries Service (2005) Endangered Species Act Section 7: final biological opinion on the Kensington Gold Project, 18 March 2005. Alaska Regional Office, Anchorage, AK

Newton I (2006) Can conditions experienced during migration limit the population levels of birds? J Ornithol 147: 146-166

Nysewander DR, Evenson JR, Murphie BL, Cyra TA (2005) Report of marine bird and marine mammal component,
Puget Sound ambient monitoring program, for July 1992 to December 1999 period. Washington Department of Fish and Wildlife, Olympia, WA

> Pierce BJ, McWilliams SR (2005) Seasonal changes in composition of lipid stores in migratory birds: causes and consequences. Condor 107:269-279

Pierce BJ, McWilliams SR, Place AR, Huguenin MA (2004) Diet preferences for specific fatty acids and their effect on composition of fat reserves in migratory red-eyed vireos (Vireo olivaceous). Comp Biochem Physiol A 138:503-514

President, Proclamation (2000) Executive Order 13158, Marine protected areas. USA Federal Register 65 (26 May 2000): 34909-34911. Microfiche

Pritchett M, Dressel S, Monagle K (2007) Berner's Bay herring research for 2005 and 2006. Report No. 1J07-01, Alaska Department of Fish and Game Regional Information, Douglas, AK

Ramenofsky M (1990) Fat storage and fat metabolism in relation to migration. In: Gwinner E (ed) Bird migration: physiology and ecophysiology. Springer-Verlag, Berlin, p 214-231

Rising JD, Somers KM (1989) The measurement of overall body size in birds. Auk 106:666-674

SAS (2002) JMP software, Version 5.0.1. SAS Institute, Cary, $\mathrm{NC}$

Sheskin DJ (2007) Handbook of parametric and nonparametric statistical procedures, 4th edn. Chapman \& Hall/CRC, Boca Raton, FL

> Stewart-Oaten A, Murdoch WW, Parker KR (1986) Environmental impact assessment: 'Pseudoreplication' in time? Ecology 67:929-940

Stick KC (2005) 2004 Washington State herring stock status report. SS 05-01, Washington Department of Fish and Wildlife, Olympia, WA

Stout HA, Gustafson RG, Lenarz WH, McCain BB, VanDoornik DM, Builder TL, Methot RD (2001) Status review of Pacific herring (Clupea pallasi) in Puget Sound, Washington. NOAA Tech Memo NMFS-NWFSC-45

Toresen R, Østvedt OJ (2000) Variation in abundance of Norwegian spring-spawning herring (Clupea harengus, Clupeidae) throughout the 20th century and the influence of climatic fluctuations. Fish Fish 1:231-256

Varpe $\varnothing$, Fiksen $\varnothing$, Slotte A (2005) Meta-ecosystems and biological energy transport from ocean to coast: the ecological importance of herring migration. Oecologia 146: 443-451

Wang SW, Iverson SJ, Springer AM, Hatch SA (2007) Fatty acid signatures of stomach oil and adipose tissue of northern fulmars (Fulmarus glacialis) in Alaska: implications for diet analysis of procellariiform birds. J Comp Physiol B 177:893-903

Williams EH, Quinn TJ II (2000) Pacific herring, Clupea pallasi, recruitment in the Bering Sea and north-east Pacific Ocean. II. Relationships to environmental variables and implications for forecasting. Fish Oceanogr 9:300-315

Williams TD, Warnock N, Takekawa JY, Bishop MA (2007) Flyway-scale variation in plasma triglyceride levels as an index of refueling rate in spring-migrating western sandpipers (Calidris mauri). Auk 124:886-897

Willson MF, Womble JN (2006) Vertebrate exploitation of pulsed marine prey: a review and the example of spawning herring. Rev Fish Biol Fish 16:183-200

- Worm B, Lotze HK, Myers RA (2003) Predator diversity hotspots in the blue ocean. Proc Natl Acad Sci USA 100: 9884-9888

Submitted: October 24, 2008; Accepted: April 6, 2009

Proofs received from author(s): June 17, 2009 